\title{
How Waterlogged Conditions Influence the Nitrogen Dynamics in a Soil-Water-Plant System: Implications for Wetland Restoration
}

\author{
Lumeng Xie ${ }^{1,2}$, Ying Liu ${ }^{1,2}$, Shiqiang Zhao ${ }^{1,2}$, Liyi Dai ${ }^{1,2}$, Zhifa Zhang ${ }^{3}$, Mingxiang Zhang ${ }^{1,2, *}$ \\ and Zhenming Zhang ${ }^{1,2, *}$ \\ 1 College of Ecology and Nature Conservation, Beijing Forestry University, Beijing 100083, China; \\ xielumeng@bjfu.edu.cn (L.X.); 18810765270@163.com (Y.L.); realzhaoshiqiang@126.com (S.Z.); \\ wolf527251312@gmail.com (L.D.) \\ 2 The Key Laboratory of Ecological Protection in the Yellow River Basin of National Forestry and Grassland \\ Administration, Beijing 100083, China \\ 3 Management and Service Center of Huangshui National Wetland Park, Xining 810008, China; \\ ecohydrology010@126.com \\ * Correspondence: zhangmingxiang@bjfu.edu.cn (M.Z.); zhenmingzhang@bjfu.edu.cn (Z.Z.); \\ Tel.: +86-136-0129-6335 (Z.Z.)
}

check for updates

Citation: Xie, L.; Liu, Y.; Zhao, S.; Dai, L.; Zhang, Z.; Zhang, M.; Zhang, Z. How Waterlogged Conditions

Influence the Nitrogen Dynamics in a Soil-Water-Plant System: Implications for Wetland Restoration. Water 2021, 13, 2957. https://doi.org/10.3390/ w13212957

Academic Editors: Junhong Bai, Tian Xie and Laibin Huang

Received: 15 August 2021

Accepted: 13 October 2021

Published: 20 October 2021

Publisher's Note: MDPI stays neutral with regard to jurisdictional claims in published maps and institutional affiliations.

Copyright: (c) 2021 by the authors. Licensee MDPI, Basel, Switzerland. This article is an open access article distributed under the terms and conditions of the Creative Commons Attribution (CC BY) license (https:/ / creativecommons.org/licenses/by/ $4.0 /)$.

\begin{abstract}
Growing populations and industrialization have led to increased nitrogen (N) loads in wetland ecosystems. A micro-constructed wetland planted with Lythrum salicaria L. to treat artificial wastewater was used to investigate the short-term variations in the plant biomass and dynamics of total nitrogen (TN) content. Our results showed that the biomass of Lythrum salicaria L. rapidly increased during the experiment due to their extensive root system and vigorous spread, and waterlogged conditions had little effect on the relationship between biomass and the TN content in soil and effluent. Under different waterlogged conditions, the TN removal rates in the water were all greater than $60 \%$, providing a reference for the waterlogged conditions used in wetland eutrophication restoration.
\end{abstract}

Keywords: eutrophication; waterlogged conditions; soil-water-plant system; constructed wetland; water purification

\section{Introduction}

The rapid development of society and intensification in agriculture has improved living standards but also caused various water-related issues, especially pollution and the degradation of wetland ecosystems [1-3]. Moreover, conditions are worsening in developing economies due to the integrated effect of anthropogenic activities, escalating demand of resources, and population explosion [4]. Different pollutants released into water bodies ultimately finds their way to natural waterways [5]. When the quality of incoming water is heavily degraded, the retention of excessive nutrients will seriously affect the wetland's ecological services.

Wetlands are transition zones between land ecosystems and aquatic ecosystems and are also soil-water-plant systems; as such, they represent a special natural complex with unique hydrological characteristics [6]. The plant communities, soil properties, and biogeochemical cycling in wetland systems are affected by water-level fluctuations and associated processes [7-9]. Small alterations in the hydrological regime can change the conditions of vegetation growth [10] and nutrient loading [11], which not only affect the vegetation patterns and nutrient cycling [12], but also control the evolution of the wetland, which is the most important variable in the formation and maintenance of special wetland types (such as coastal wetland, swamp, and marsh) and processes.

However, wetlands provide a crucial nature-based solution for river-water purification. The traditional perception of wetlands as nutrient sinks has led them to be used as 
wastewater disposal areas. The ecological quality of these multi-purpose ecosystems could be disrupted due to an overload of nutrients and other pollutants [13], and the excessive loading of nutrient elements into natural water bodies, enhancing the risk of eutrophication. Therefore, effective and cost-efficient onsite treatment to remove the contaminants is a critical issue in water protection and risk mitigation [14].

Plants offer an added benefit to wetland restoration and are effective in mitigating wetland eutrophication by absorbing, assimilating, and reutilizing nutrients such as nitrogen and phosphorus in the water body and sediment to support their own physiological processes and growth for the following year [15-20]. Wetland plant roots share some common characteristics, such as providing oxygen and secreting oxygen to form aerobic, facultative and anaerobic micro-environments around the rhizosphere, thereby promoting the degradation of pollutants in sewage by microbial nitrification and denitrification [21]. The ability to accumulate different element contents in various organs is a good predictor of wetland's efficiency and proficiency in nutrient resorption [22-24].

Waterlogged events impact soil properties and modify enzyme activities [25]. Alternating waterlogged conditions can significantly increase nutrient removal efficiency compared with permanently flooded soils and non-flooded soils [26]. When $\mathrm{O}_{2}$ is less available and soil redox potential is more reduced, slow organic matter decomposition may result in an accumulation of dissolved organic carbon [27]. Redox potential decreases more slowly under flooding-draining soils than under permanently flooded soils [28]. The aerobic/anaerobic biogeochemical equilibrium, nutrient inputs and outputs, and the structure of plant communities could, in all likelihood, be strongly disturbed during the waterlogged process and could further impact soil nutrient contents.

Previous researchers have focused on nitrogen removal in wetland systems under the condition of single wetland plants or a variety of ecological combinations of wetland plants [29], as well as system nitrogen retention under constant conditions [30-32]; however, these studies did not always relate waterlogged conditions to the removal of nutrient elements. Here, we use a micro-constructed wetland system to simulate the nitrogen removal process under different waterlogged conditions, track dynamic changes in nitrogen elements in the soil-water-system, and further clarify the impact of different waterlogged conditions on plant growth, pollutant removal, and nitrogen retention. At the same time, suggestions are given for future research focused on the purification and restoration of wetland pollution under different waterlogged conditions, which lay the theoretical foundation and provide a reference for the selection of waterlogged conditions for further wetland restoration.

\section{Materials and Methods}

\subsection{Material Preparations}

This study was carried out from June 2018 to October 2018. Considering both its pollution resistance and tolerance, we selected Lythrum salicaria L., a type of ornamental wetland plant species that can grow under different environment conditions [33,34]. Plant samples were purchased online from a horticultural company (www.taobao.com) (accessed on 24 June 2018) in June 2018. Twelve individuals were ultimately evenly planted e in each compartment of flumes for one month. Three compartments formed a group; the growth of individuals in each flume was approximately the same.

The experimental water was a high-content eutrophication sewage prepared in the laboratory according to relevant research [35]; its main reagents and target contents are shown in Table 1. Distilled water was used to water the plants every three days during the experimental period. Then, influent nutrient contents greatly exceeded the environmental limit values. 
Table 1. Artificial sewage water characteristics.

\begin{tabular}{cccc}
\hline Constituent $^{\text {a }}$ & TN (mg/L) & TP (mg/L) & COD (mg/L) \\
\hline Content & 40 & 4 & 300 \\
\hline Reagent & $\mathrm{NH}_{4} \mathrm{CI}$ & $\mathrm{KH}_{2} \mathrm{PO}_{4}$ & $\mathrm{C}_{6} \mathrm{H}_{12} \mathrm{O}_{6}$ \\
\hline
\end{tabular}

a The configuration of the artificial sewage was adopted from a similar experiment [22].

The experiment was located in a greenhouse at Beijing Forestry University in Haidian District. During the experiment, the mean temperature was $25^{\circ} \mathrm{C}$ and the relative humidity was $74.2 \%$. We set up a flume (shown in Figure 1) containing six compartments filled with $0.12 \mathrm{~m}$ deep non-contaminated soil collected from outside of the greenhouse to simulate the conditions of a surface flow constructed wetland. To collect water samples during the experiment, two outlets were placed $0.1 \mathrm{~m}$ and $0.2 \mathrm{~m}$ from the lower edge of the flume. We used a steel canopy to prevent from rain entering the system.
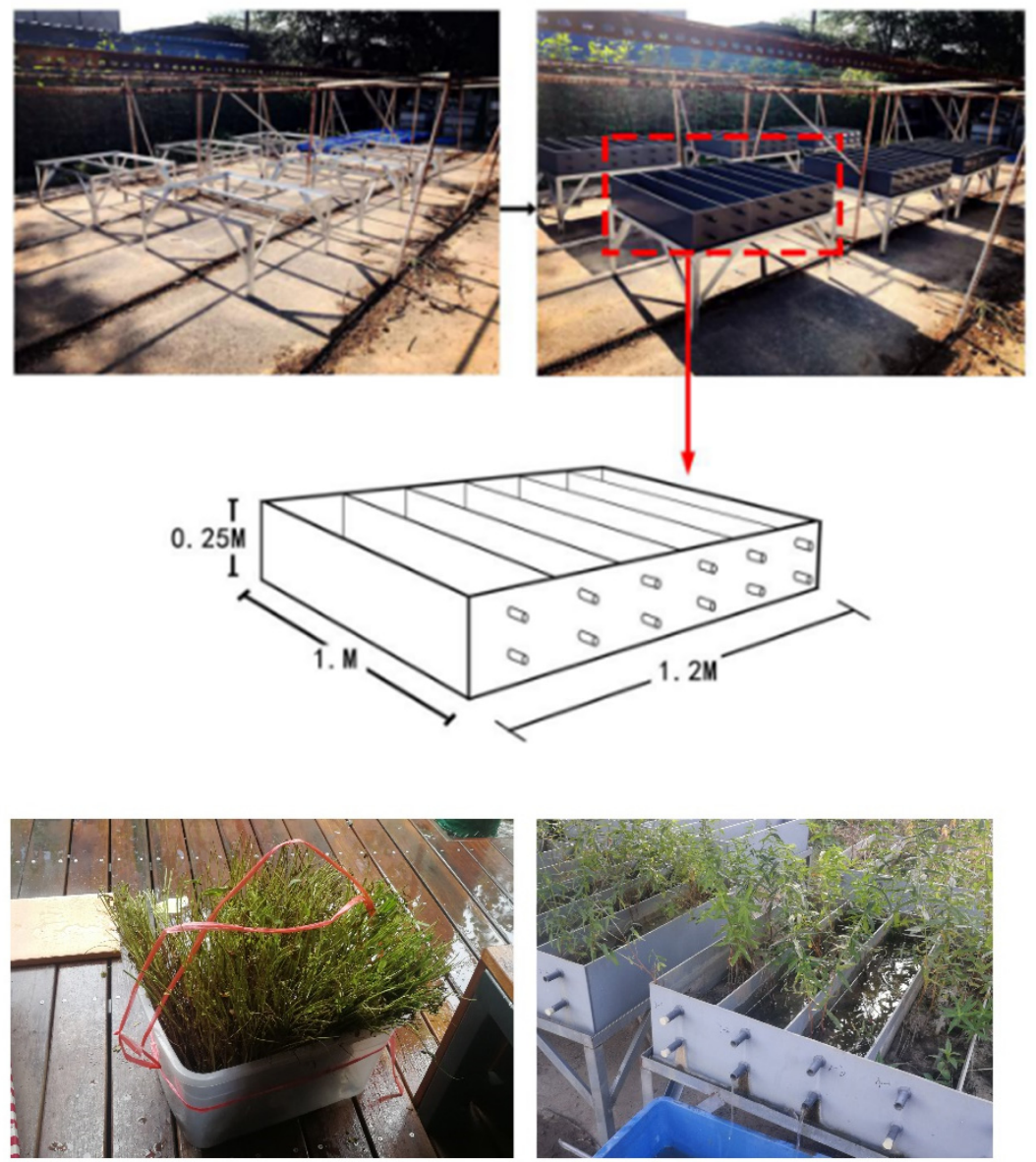

Figure 1. Diagram of flume.

\subsection{Sample Treatment}

We used a completely randomized design, and the experiment considered two factors (shown in Figure 2): (i) waterlogged depth $(10 \mathrm{~cm}$ and $20 \mathrm{~cm}$ ) and (ii) waterlogged frequency (7 days and 14 days). To simulate the hydrological fluctuation scenarios naturally occurring in wetland, we conducted four treatments: (i) high waterlogged frequency and low waterlogged depth, (ii) high waterlogged frequency and high waterlogged depth, (iii) low waterlogged frequency and low waterlogged depth, and (iv) low waterlogged frequency and high waterlogged depth. The experiment was conducted indoors in six flumes, with three replicates in each treatment. 


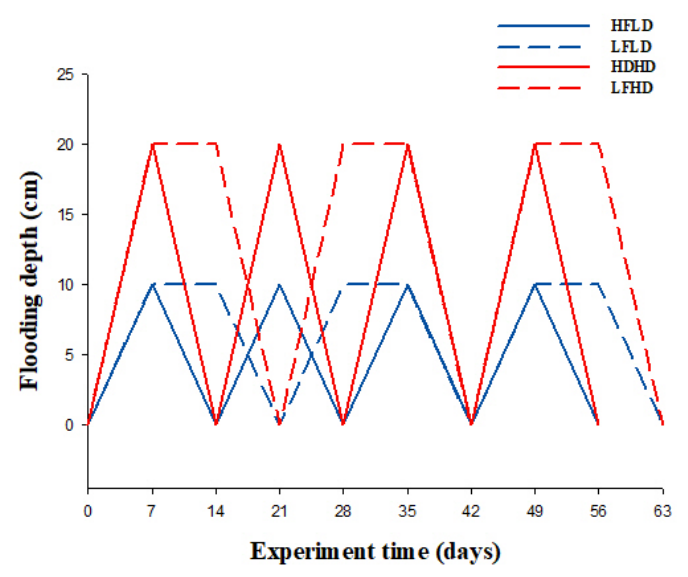

Figure 2. Experiment period.

The artificial pollution water was kept in plastic buckets, carried from the laboratory to the greenhouse, and released into the flumes before starting the experiments. In order to keep the waterlogged depth unchanged, we added water to the flumes every two days to compensate for losses due to evaporation. To maintain a high waterlogged frequency, we drained water every 7 days, whereas to achieve low waterlogged frequency, we drained water every 14 days.

\subsection{Sample Collection and Analysis}

As the water passed through each compartment of the flumes, the biomass and TN contents of the water and soil were monitored. We collected plant, soil, and water samples every seven days from each group of the flumes. All plant and soil samples were placed in plastic bags and immediately brought to the laboratory. The plants samples were first washed with running tap water, and air-dried at room temperature for two weeks. Recognizable plant litter, coarse root materials, and stones were removed from the plant and soil samples.

Fresh plant samples were separated into their above- and below-ground components and then dried in an oven at $70{ }^{\circ} \mathrm{C}$ for $48 \mathrm{~h}$ for dry-weight determination. Dried soil samples were ground, wet-digested, and analyzed for TN. The water samples were placed in plastic bottles and stored at $2{ }^{\circ} \mathrm{C}$ prior to analysis. We used an Elemental Analyzer (Vario EI, Elementar Co., Langenselbold, Germany) to obtain the TN content.

\subsection{Statistical Analysis and Graphing}

All experimental data are presented as average values. One-way ANOVA analysis was conducted to reveal the differences in average biomass and TN content between the highwaterlogged-frequency/low-waterlogged-frequency and high-waterlogged-depth/lowwaterlogged depth treatments. The data obtained in the experiment were edited and processed by Microsoft Excel 2007 software; relevant charts were drawn using Sigmaplot 12.5 software; one-way ANOVA analysis and Chi-Square tests were carried out using SPSS22.0. The formula for the TN removal rate was as follows:

$$
\text { Removal rate }(\%)=\left(C_{0}-C_{1}\right) / C_{0} \times 100 \%
$$

where $C_{0}$ is the initial content and $C_{1}$ is the content at time of sampling.

\section{Results}

\subsection{Dynamic Changes in Average Biomass under Different Waterlogged Conditions}

The results of the Chi-Square Tests showed that different waterlogged conditions have no effect on plant growth $(p=0.271>0.05$ for aboveground biomass, $p=0.349>0.05$ for underground biomass). Generally, the aboveground biomass first increased and then 
decreased with increasing experiment time. The changes in aboveground biomass for a high waterlogged frequency were similar to those for a low frequency, although the values were slightly higher for the low waterlogged frequency (Figure 3a). The initial aboveground biomass was $3.05 \pm 0.30 \mathrm{~g}$. This reached a maximum value of $4.73 \pm 0.47 \mathrm{~g}$ under the high waterlogged frequency, and $5.05 \pm 0.82 \mathrm{~g}$ under the low waterlogged frequency, at 42 days.

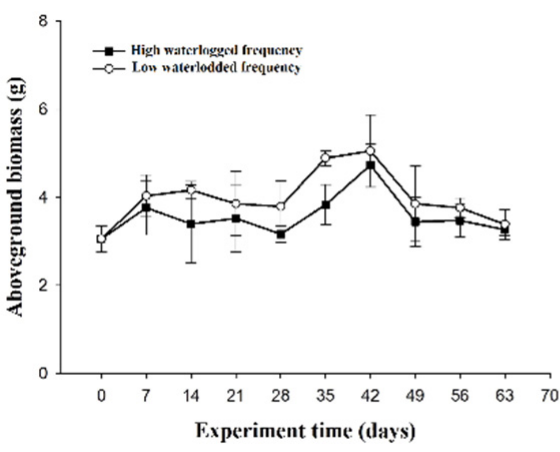

a

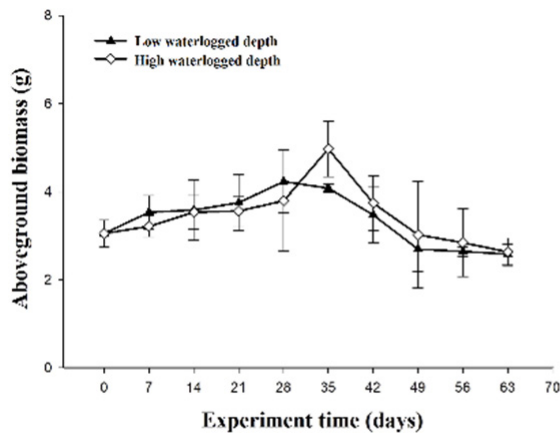

C

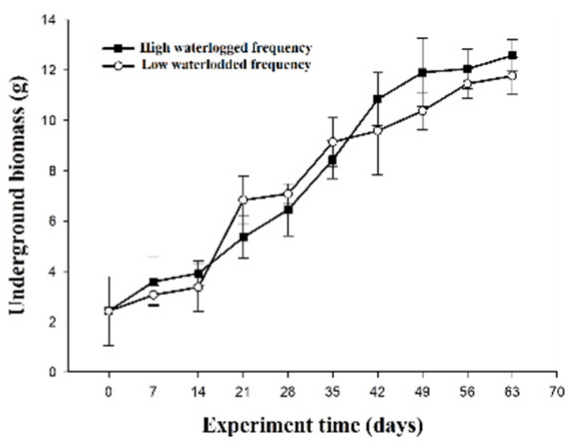

b

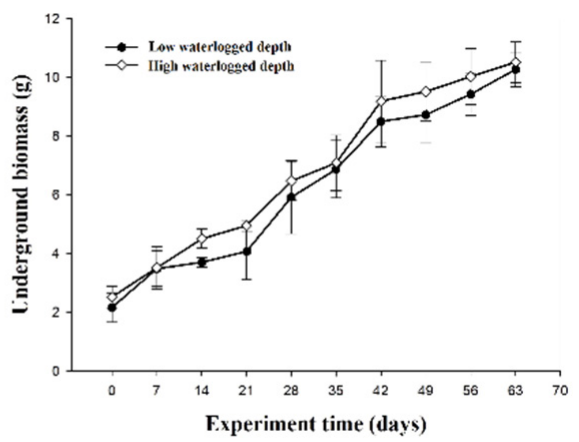

d

Figure 3. Dynamic changes in average biomass under different waterlogged conditions. (a) aboveground biomass of different waterlogged frequencies applied to the average of waterlogged depth option; (b) underground biomass of different waterlogged frequencies applied to the average of waterlogged depth option; (c) aboveground biomass of different waterlogged depths applied to the average of waterlogged frequencies option; (d) underground biomass of different waterlogged depths applied to the average of waterlogged frequencies option.

The underground biomass gradually increased during the experimental period under different waterlogged conditions. At the beginning ( 0 to 14 days) and end (last 28 days) of the experiment, the underground biomass under the high waterlogged frequency was higher than that under the low waterlogged frequency (Figure $3 b$ ). For the high waterlogged frequency condition, underground biomass increased from $2.42 \pm 0.37 \mathrm{~g}$ to $12.58 \pm 0.63 \mathrm{~g}$, whereas it was $11.77 \pm 0.74 \mathrm{~g}$ at the end of the experiment under the low waterlogged frequency. The one-way ANOVA results showed that waterlogged frequency did not affect the aboveground $(p=0.103>0.05)$ or underground $(p=0.961>0.05)$ biomass of the wetland plant.

At a low waterlogged depth, the aboveground biomass decreased from $3.05 \pm 0.30 \mathrm{~g}$ to $2.58 \pm 0.23 \mathrm{~g}$ over the course of the experiment, with the maximum value of $4.23 \pm 0.71 \mathrm{~g}$ occurring on the 28th day. At a high waterlogged depth, the aboveground biomass decreased from $3.05 \pm 0.30 \mathrm{~g}$ to $2.63 \pm 0.31 \mathrm{~g}$ over the entire experiment, with the maximum (4.97 $\pm 0.63 \mathrm{~g}$ ) occurring 35 days after treatment (Figure 3c).

The underground biomass displayed clear trends in the experiment. All curves increased, and we observed that the value under the low waterlogged depth was always higher than that under the high waterlogged depth (Figure 3d). The fastest growth in 
the underground biomass was between the 21st and 42nd day. The results of one-way ANOVA showed that waterlogged depth did not affect the aboveground $(p=0.796>0.05)$ or underground $(p=0.693>0.05)$ biomass of the wetland plant.

\subsection{Dynamic Changes in Total Nitrogen Content under Different Waterlogged Conditions}

The results of Chi-Square tests showed that different waterlogged conditions have no effect on TN content in soil ( $p=0.814>0.05)$ and effluent $(p=0.754>0.05)$. At the beginning of the experiment, the soil TN content was $0.45 \pm 0.03 \mathrm{~g} / \mathrm{kg}$, with this value changing during the experiment. Under the high-waterlogged-frequency condition, this increased from 0 to 35 days, before falling smoothly from $0.62 \pm 0.02 \mathrm{~g} / \mathrm{kg}$ to $0.54 \pm 0.038 \mathrm{~g} / \mathrm{kg}$ and then rebounding slightly after 49 days. Under the low-waterlogged-frequency condition, the value increased from 0 to 14 days, decreased on the 21st day, and continued to rise from 21 to 35 days, reaching a maximum content of $0.63 \pm 0.045 \mathrm{~g} / \mathrm{kg}$ on the 35 th day. Under the two experimental conditions, the TN content at each sampling time was higher than that at the beginning of the experiment (Figure 4a). One-way ANOVA showed that the different waterlogged frequencies did not affect the content of TN in soil $(p=0.300>0.05)$.
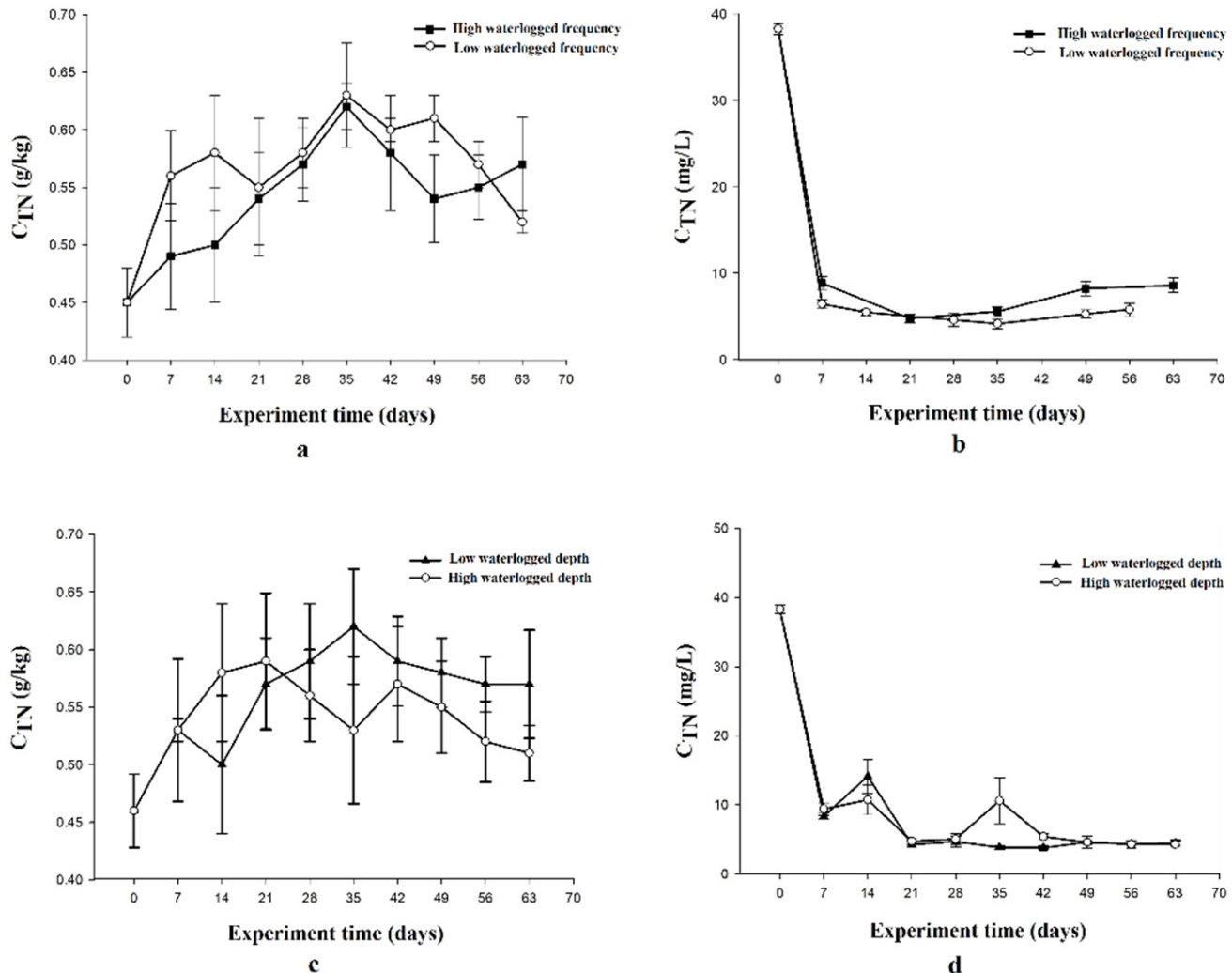

Figure 4. Dynamic changes in total nitrogen content of soil and effluent under different waterlogged conditions. (a) The dynamic changes in soil TN content under different waterlogged frequencies applied to the average of waterlogged depth option; (b) The dynamic changes in effluent TN content under different waterlogged frequencies applied to the average of waterlogged depth option; (c) The dynamic changes in soil TN content under different waterlogged depths applied to the average of waterlogged frequencies option; (d) The dynamic changes in effluent TN content under different waterlogged depth applied to the average of waterlogged frequencies option.

The TN content of the effluent represents the purification capacity of the wetland plants. Regarding the dynamic changes in effluent TN content under each waterlogged frequency, there was an overall decreasing trend during the experiment, although there was a slight increase towards the end of the experiment (Figure $4 \mathrm{~b}$ ). There were five periods under a high waterlogged frequency and three periods under a low waterlogged frequency. 
Compared with the influent, the TN content in the effluent was significantly lower. The average removal rate of $\mathrm{TN}$ is shown in Table 2.

Table 2. Average removal rate of effluent total nitrogen under different waterlogged frequencies.

\begin{tabular}{cccccc}
\hline & Period 1 & Period 2 & Period 3 & Period 4 & Period 5 \\
\hline $\begin{array}{c}\text { High waterlogged } \\
\text { frequency }\end{array}$ & $76.8 \pm 2.1 \%$ & $87.6 \pm 1.6 \%$ & $85.4 \pm 1.9 \%$ & $78.5 \pm 4.1 \%$ & $77.6 \pm 4.5 \%$ \\
\hline & Period 1 & Period 2 & Period 3 & \\
\hline $\begin{array}{c}\text { Low waterlogged } \\
\text { frequency }\end{array}$ & $88.0 \pm 3.9 \%$ & $89.2 \pm 1.9 \%$ & $84.9 \pm 4.4 \%$ & \\
\hline
\end{tabular}

Short-term changes in waterlogged depth were associated with fluctuations in soil TN content. With increased inputs of artificial simulated pollution water, the general trend in soil TN content was an initial increase, followed by a decrease (Figure 4c). Under the low waterlogged depth, the maximum TN value was observed on the 35th day, after which it declined slowly. Under the high waterlogged depth, the peak TN content of occurred on the 21st day. We also observed that the TN content of each sample was higher than that at the beginning of the experiment. The one-way ANOVA indicated that waterlogged depth did not affect soil TN content $(p=0.366>0.05)$.

Overall, TN content in effluent under different waterlogged depths showed a downward trend during the experiment (Figure 4d). On the 35th day, the TN content of the effluent was $3.81 \pm 0.24 \mathrm{mg} / \mathrm{L}$ under the low waterlogged depth and $10.59 \pm 3.32 \mathrm{mg} / \mathrm{L}$ under the high waterlogged depth, which was a significant difference. The TN removal rate of the system was more than $60 \%$. In general, the system could remove the TN in the water during the plant-growth period, and the overall removal rate showed an increasing trend. Table 3 shows the TN average removal rates. The one-way ANOVA analysis showed that different waterlogged depths did not affect the TN content in effluent $(p=1.00>0.05)$.

Table 3. Average removal rate of effluent total nitrogen under different waterlogged depth.

\begin{tabular}{|c|c|c|c|c|c|c|c|c|c|}
\hline & 7 & 14 & 21 & 28 & 35 & 42 & 49 & 56 & 63 \\
\hline $\begin{array}{c}\text { High waterlogged } \\
\text { depth }\end{array}$ & $78.2 \pm 0.9 \%$ & $63.1 \pm 8.4 \%$ & $88.9 \pm 0.8 \%$ & $87.8 \pm 2.6 \%$ & $90.1 \pm 8.5 \%$ & $90.2 \pm 0.8 \%$ & $88.0 \pm 2.9 \%$ & $89.1 \pm 2.3 \%$ & $88.4 \pm 1.4 \%$ \\
\hline $\begin{array}{c}\text { Low waterlogged } \\
\text { depth }\end{array}$ & $75.5 \pm 2.9 \%$ & $72.0 \pm 7.4 \%$ & $87.7 \pm 1.4 \%$ & $86.9 \pm 2.6 \%$ & $72.4 \pm 0.6 \%$ & $85.9 \pm 1.1 \%$ & $88.1 \pm 0.4 \%$ & $88.8 \pm 1.6 \%$ & $88.9 \pm 1.5 \%$ \\
\hline
\end{tabular}

\section{Discussion}

As shown by the results of the statistical analysis, different waterlogged conditions had no link between biomass and TN content in the wetland system. A possible reason for this may be that this constructed wetland system was not sensitive to the waterlogged conditions we designed; the two different waterlogged conditions are similar to the constructed wetlands system. However, some general rules were observed based on the change trends, and with implications for wetland water environment restoration.

Wetland soil greatly contributes to water purification, nutrient accumulation, and the regeneration of nitrogen, with its function being largely dependent on the plant community structure [36]. The notable reductions in effluent TN content indicated that this constructed wetland was able to remove TN from the influent water and that the investigated soil's ability to retain TN was also high. To a certain extent, the increase in plant biomass indicated that the $\mathrm{N}$ is assimilated and absorbed by wetland plants in different forms $[37,38]$, and vegetation harvesting may simulate the overall $\mathrm{N}$ removal [39]; these processes also caused the decrease in TN content in water. Vegetation covering was essential to the enrichment of $\mathrm{TN}$, indicating the importance of biologically related fixation in wetland soil [20]. 
According to the changes in biomass at the beginning of the experiment, the plants grew vigorously, because eutrophication stimulates the growth in wetland plant life [40]. Waterlogged conditions are an important factor affecting the growth and reproduction of wetland plants, with different wetland plants having different requirements in relation to waterlogged conditions; moreover, the change in biomass is a comprehensive response to the change in the external environment [41]. In this experiment, for both high and low waterlogged frequencies, an increasing then decreasing trend was observed in aboveground biomass. The aboveground biomass continued to decline towards the end of the experiment, which may be due to the weather and the physiological state of the plant. Overall, the aboveground biomass was higher under a low waterlogged frequency, and the belowground biomass was higher under a high waterlogged frequency, indicating that Lythrum salicaria L. may be less productive with a fluctuating water level than with a stable water level. We also observed that most of the biomass was concentrated in the belowground portion; therefore, Lythrum salicaria L. may rely on increases in its root biomass to acquire nitrogen from soil under a eutrophic environment. The usual plant response to waterlogged stress is to extend the stem. Therefore, biomass of the aboveground portion will be relatively large [42]. When the waterlogged depth is less than $1 \mathrm{~m}$, some emergent plants will also distribute more biomass to the stem [43]. Water-level fluctuations will also intermittently reduce the atmospheric sources of carbon and oxygen; therefore, if the plant is submerged for a long time, it will force its below-ground portion to conduct anaerobic respiration, which quickly depletes the carbohydrate reserve and reduces net growth [17]. From another perspective, in addition to being affected by water level, some wetland plants are also greatly affected by the nutrient conditions of the substrate [44,45].

During the experiment, the TN content in the soil was higher than that at the beginning of the experiment, which indicates that nitrogenous components of the water body became accumulated in the soil. At the beginning of the experiment, the value of the TN content in influent was $38.31 \pm 0.62 \mathrm{mg} / \mathrm{L}$, meaning that the TN load was very high. TN retention efficiency was inversely correlated with the load in the wetland system, with high loads reducing the efficiency of removal [46]. According to previous research, nitrogen was initially mostly in the form of $\mathrm{NH}_{4}{ }^{+}$and may have been partially sorbed onto the soil by cation exchange processes [47]. Under anoxic conditions in unharvested systems, $\mathrm{NO}_{3}{ }^{-}$ can be further transformed by denitrifying bacteria to $\mathrm{N}_{2}$ gases, using carbon as both the electron donor and the growth element [36]. Under flooded conditions, the soil will form a narrow oxidation zone of $0-1 \mathrm{~cm}$ on the wetland surface, and denitrification will occur when there is a lack of oxygen [48]. This converts the nitrogen that already exists in the system into a gas and returns it to the atmosphere, thus optimizing the eutrophication environment. Under the condition of low waterlogged frequency, the TN content in the soil in the first week of being waterlogged (the 21st, 42nd, and 63rd days) was lower than that in the previous week, indicating that the soil could degrade nitrogenous components without additional nitrogen inputs; this trend was not obvious under the high-waterloggedfrequency condition.

In this experiment, the nitrogen content of the soil first increased and then decreased under different waterlogged depths. Under the high-waterlogged-depth condition, the nitrogen content decreased after 21 days; under the low-waterlogged-depth condition, a similar trend appeared after 35 days. When the water level is high, plants increase the rate of root oxygen secretion, providing more oxygen to the roots; thus, the plant roots can form an aerobic microenvironment and improve nitrification intensity. Moreover, the downward migration of $\mathrm{NO}_{3}{ }^{-}$from water to soil affects the denitrification of nitrogen. Owing to the increase in the vertical diffusion flux of dissolved nitrogen, the denitrification rate will be significantly improved, and the removal efficiency of nitrogen will be higher. Therefore, it is predicted that, with an increase in water level, the nitrogen storage of wetland soil will gradually decrease.

Irrespective of waterlogged conditions, the highest removal efficiency of TN appeared between the 14th and 35th days. This was the peak period of removal efficiency, possibly 
due to plants at the beginning of the experiment requiring lots of nutrients to grow stably. At the end of the experiment, the TN concentration in the effluent increased slightly, reflecting the reduced demand for nutrients. Secondary pollution resulting from shoot death is a difficult problem, which complicates the application of wetland plants for water purification [49]. Although the removal rates were all at a high level, only a few effluent samples could meet the rate $\mathrm{V}$ standard $(\mathrm{TN} \leq 2 \mathrm{mg} / \mathrm{L}$ ) given in China's environmental quality standards for TN in surface water.

Under the two waterlogged conditions, the removal rates of TN from the water were all greater than $60 \%$. After the 21st day, we saw peak TN removal. On the 35th day, the removal effect for the low waterlogged depth was significantly better than that of the high waterlogged depth; it is considered that the larger hydraulic load of the high waterlogged depth, which exceeded the optimal value, caused this difference. Within a certain range, the removal rate of nitrogen from water increases with the increase in nitrogen load. In this experiment, the TN concentration in the influent was $38.31 \pm 0.62 \mathrm{mg} / \mathrm{L}$, and plants showed a marked purification effect. Another possible reason for this is that the root system of Lythrum salicaria $\mathrm{L}$. is highly developed and can very effectively absorb the nutrients from water to maintain the growth demand, because we observed that the underground biomass gradually increased during the experimental period. The root system of plants is directly proportional to the purification capacity of sewage, and the microorganism population on the root system is a key factor in the removal of pollutants. Plants synthesize oxygen through photosynthesis and release it to their roots through plant ventilation tissue. This process can form an aerobic-anoxic-anaerobic microenvironment around the roots, promoting the process of nitrification or denitrification through the microorganisms and indirectly increasing the removal capacity of nitrogen pollutants [50].

\section{Conclusions}

(1) Under a eutrophication environment, the biomass of Lythrum salicaria L. increased rapidly during the experiment, due to its extensive root system and vigorous spread, but it was not affected by waterlogged frequency ( 1 week or 2 weeks) or waterlogged depth $(10 \mathrm{~cm}$ or $20 \mathrm{~cm})$.

(2) Under different waterlogged conditions, the removal rates of TN from the water were consistently greater than $60 \%$. When the growth trend slowed, the removal efficiency tended to be stable and then decreased. Therefore, when removing nitrogen from water by plants, we should consider regular harvesting to remove the enriched TN content in the system.

(3) The removal efficiency of TN in soil and water was more obvious under low waterlogged frequencies. A high waterlogged depth may promote denitrification and nitrogen degradation in soil, and it is predicted that, with an increase in water level, the nitrogen storage of wetland soil will gradually decrease. However, high nutrient loads may reduce the removal rate of $\mathrm{TN}$ in water.

(4) When implementing wetland water restoration projects, waterlogged frequency and depth should be considered. In our experiment, the waterlogged frequency was generally high and waterlogged depth was low compared with the actual conditions in most wetlands, but the nitrogen removal performance was pretty good. Therefore, biomanipulation, when appropriately timed in accordance with low waterlogged depths and high waterlogged frequencies, may be a low-cost-high-benefit tool for wetland eutrophication abatement.

The current studies demonstrate that the cultivation of plants in constructed wetland can successfully reduce the nitrogen concentration from wastewater. Despite this, extensive research is still required, because different plant species have different nitrogen removal capacities, and in order to improve wetland restoration, more varied waterlogged conditions are needed. 
Author Contributions: L.X. designed the experiment and write the manuscript, Y.L., S.Z. and L.D. participated this experiment and contributed to the paper outline, Z.Z. (Zhifa Zhang) and Z.Z. (Zhenming Zhang) edited this paper and contributed to the writing, M.Z. administrated the project. All authors have read and agreed to the published version of the manuscript.

Funding: This research was supported by the Fundamental Research Funds for the Central Universities in China (GK122101267).

Institutional Review Board Statement: Not applicable.

Informed Consent Statement: Not applicable.

Data Availability Statement: The data presented in this study are available on request from the corresponding author.

Conflicts of Interest: The authors have no conflict of interest.

\section{References}

1. Meng, B.; Liu, J.-l.; Bao, K.; Sun, B. Water fluxes of Nenjiang River Basin with ecological network analysis: Conflict and coordination between agricultural development and wetland restoration. J. Clean. Prod. 2019, 213, 933-943. [CrossRef]

2. Abi Saab, M.T.; Jammoul, D.; Makhlouf, H.; Fahed, S.; Lebbous, N.; Hajjar, C.; Abi Saad, R.; Younes, M.; Hajj, M.; Todorovic, M. Assessing the performance of constructed wetland for water quality management of a Southern Mediterranean river. Water Environ. J. 2018, 32, 508-518. [CrossRef]

3. Van Meter, K.J.; Basu, N.B.; Van Cappellen, P. Two centuries of nitrogen dynamics: Legacy sources and sinks in the Mississippi and Susquehanna River Basins. Glob. Biogeochem. Cycles 2017, 31, 2-23. [CrossRef]

4. Suhani, I.; Monika; Vaish, B.; Singh, P.; Singh, R.P. Restoration, Construction, and Conservation of Degrading Wetlands: A Step toward Sustainable Management Practices; Springer: Singapore, 2020.

5. Vkm, A.; Rsa, B.; Nks, B. Application of constructed wetland; a natural treatment system for environmentally sustainable domestic sewage treatment. Sustain. Environ. Clean-Up 2021, 105-129. [CrossRef]

6. Maltby, E. Wetland management goals: Wise use and conservation. Landsc. Urban Plan. 1991, 20, 9-18. [CrossRef]

7. Bai, J.; Ouyang, H.; Deng, W.; Zhu, Y.; Zhang, X.; Wang, Q. Spatial distribution characteristics of organic matter and total nitrogen of marsh soils in river marginal wetlands. Geoderma 2005, 124, 181-192. [CrossRef]

8. Unger, I.M.; Kennedy, A.C.; Muzika, R.-M. Flooding effects on soil microbial communities. Appl. Soil Ecol. 2009, 42, 1-8. [CrossRef]

9. Luo, F.-L.; Jiang, X.-X.; Li, H.-L.; Yu, F.-H. Does hydrological fluctuation alter impacts of species richness on biomass in wetland plant communities? J. Plant Ecol. 2016, 9, 434-441. [CrossRef]

10. Toogood, S.E.; Joyce, C.B.; Waite, S. Response of floodplain grassland plant communities to altered water regimes. Plant Ecol. 2007, 197, 285-298. [CrossRef]

11. Sánchez-Carrillo, S.; Angeler, D.G.; Lvarez-Cobelas, M.; Sánchez-Andrés, R. Freshwater Wetland Eutrophication; Springer: Dordrecht, The Netherlands, 2010.

12. Gaberščik, A.; Krek, J.L.; Zelnik, I. Habitat diversity along a hydrological gradient in a complex wetland results in high plant species diversity. Ecol. Eng. 2018, 118, 84-92. [CrossRef]

13. Sileshi, A.; Assayie, A.; Beyene, A.; Stiers, I.; Triest, L. Water Purifying Capacity of Natural Riverine Wetlands in Relation to Their Ecological Quality. Front. Environ. Sci. 2020, 8, 39. [CrossRef]

14. Bavandpour, F.; Zou, Y.; He, Y.; Saeed, T.; Sun, Y.; Sun, G. Removal of dissolved metals in wetland columns filled with shell grits and plant biomass. Chem. Eng. J. 2018, 331, 234-241. [CrossRef]

15. Aerts, R.; Chapin, F.S. The Mineral Nutrition of Wild Plants Revisited: A Re-evaluation of Processes and Patterns. Adv. Ecol. Res. 1999, 30, 1-67. [CrossRef]

16. Rejmankova, E. Nutrient resorption in wetland macrophytes: Comparison across several regions of different nutrient status. New Phytol. 2005, 167, 471-482. [CrossRef] [PubMed]

17. Deegan, B.M.; White, S.D.; Ganf, G.G. The influence of water level fluctuations on the growth of four emergent macrophyte species. Aquat. Bot. 2007, 86, 309-315. [CrossRef]

18. Ling, Z.; Li, J. Study on removal efficiency of nitrogen and phosphorus from agricultural wastewater by subsurface flow constructed wetland./ ADVANCES IN ENERGY SCIENCE AND ENVIRONMENT ENGINEERING II. In Proceedings of the 2nd International Workshop on Advances in Energy Science and Environment Engineering (AESEE 2018), American Institute of Physics Conference Series, Zhuhai, China, 2-4 February 2018.

19. Gan, J.; Chan, S.H.; Eikaas, H.S.; Sim, C.H. Nutrient removal and plant biomass of 5 wetland plant species in Singapore. Water Pract. Technol. 2011, 6, wpt2011053. [CrossRef]

20. Ge, Z.; An, R.; Fang, S.; Lin, P.; Li, C.; Xue, J.; Yu, S. Phragmites australis + Typha latifolia Community Enhanced the Enrichment of Nitrogen and Phosphorus in the Soil of Qin Lake Wetland. Scientifica 2017, 2017, 8539093. [CrossRef]

21. Choudhury, M.I.; Segersten, J.; Hellman, M.; Mckie, B.G.; Hallin, S.; Ecke, F. Importance of plant species for nitrogen removal using constructed floating wetlands in a cold climate. Ecol. Eng. 2019, 138, 126-132. [CrossRef] 
22. Bonanno, G.; Vymazal, J.; Cirelli, G.L. Translocation, accumulation and bioindication of trace elements in wetland plants. Sci. Total Environ. 2018, 631-632, 252-261. [CrossRef]

23. Pan, X.; Ping, Y.; Cui, L.; Zhang, X.; Li, W.; Hu, Y.; Cornelissen, J.H.C. Nutrient Resorption from Leaves of Wetland Plants in a Constructed Wetland Depends on Green Leaf Nutrient Content and Life Form. Wetlands 2019, 40, 983-991. [CrossRef]

24. Wang, A.O.; Jiang, X.-X.; Zhang, Q.-Q.; Zhou, J.; Li, H.-L.; Luo, F.-L.; Zhang, M.-X.; Yu, F.-H. Nitrogen addition increases intraspecific competition in the invasive wetland plant Alternanthera philoxeroides, but not in its native congener Alternanthera sessilis. Plant Species Biol. 2015, 30, 176-183. [CrossRef]

25. Ou, Y.; Rousseau, A.N.; Wang, L.; Yan, B.; Gumiere, T.; Zhu, H. Identification of the alteration of riparian wetland on soil properties, enzyme activities and microbial communities following extreme flooding. Geoderma 2019, 337, 825-833. [CrossRef]

26. Tootoonchi, M.; Bhadha, J.H.; Lang, T.A.; McCray, J.M.; Clark, M.W.; Daroub, S.H. Reducing drainage water phosphorus content with rice cultivation under different water management regimes. Agric. Water Manag. 2018, 205, 30-37. [CrossRef]

27. Moorberg, C.J.; Vepraskas, M.J.; Niewoehner, C.P. Phosphorus Dissolution in the Rhizosphere of Bald Cypress Trees in Restored Wetland Soils. Soil Sci. Soc. Am. J. 2015, 79, 343-355. [CrossRef]

28. McHergui, C.; Besaury, L.; Langlois, E.; Aubert, M.; Akpa-Vinceslas, M.; Buatois, B.; Quillet, L.; Bureau, F. A comparison of permanent and fluctuating flooding on microbial properties in an ex-situ estuarine riparian system. Appl. Soil Ecol. 2014, 78, 1-10. [CrossRef]

29. Li, Y.; Cheng, C.; Li, X. Research Progress on Water Purification Efficiency of Multiplant Combination in Constructed Wetland. IOP Conf. Ser. Earth Environ. Sci. 2021, 632, 052051. [CrossRef]

30. Yu, X.; Konig, T.; Qi, Z.; Yongsheng, G. Nitrogen and phosphorus removal of locally adapted plant species used in constructed wetlands in China. Water Sci. Technol. 2012, 66, 695-703. [CrossRef] [PubMed]

31. Cheng, F.Y.; Meter, K.V.V.; Byrnes, D.K.; Basu, N.B. Maximizing US nitrate removal through wetland protection and restoration. Nature 2020, 588, 625-630. [CrossRef] [PubMed]

32. Audet, J.; Zak, D.; Bidstrup, J.; Hoffmann, C.C. Nitrogen and phosphorus retention in Danish restored wetlands. Ambio 2020, 49, 324-336. [CrossRef]

33. Stevens, K.J.; Peterson, R.L.; Reader, R.J. The Aerenchymatous Phellem of Lythrum salicaria (L.): A Pathway for Gas Transport and its Role in Flood Tolerance. Ann. Bot. 2002, 89, 621-625. [CrossRef] [PubMed]

34. Bastlová, D.A.; Květ, J.A.N. Differences in dry weight partitioning and flowering phenology between native and non-native plants of purple loosestrife (Lythrum salicaria L.). Flora 2002, 197, 332-340. [CrossRef]

35. Sklarz, M.Y.; Gross, A.; Yakirevich, A.; Soares, M. A recirculating vertical flow constructed wetland for the treatment of domestic wastewater. Desalination 2009, 246, 617-624. [CrossRef]

36. Gumbricht, T. Nutrient removal processes in freshwater submersed macrophyte systems. Ecol. Eng. 1993, 2, 1-30. [CrossRef]

37. Sun, H.; Xin, Q.; Luo, H.; Yan, S.; Lan, S.; Wang, Y. Effects of emerged plant on soil methane emission and nitrogen content in constructed wetland. IOP Conf. Ser. Earth Environ. Sci. 2019, 218, 012135. [CrossRef]

38. Zak, D.; Gelbrecht, J.; Zerbe, S.; Shatwell, T.; Barth, M.; Cabezas, A.; Steffenhagen, P. How helophytes influence the phosphorus cycle in degraded inundated peat soils-Implications for fen restoration. Ecol. Eng. 2014, 66, 82-90. [CrossRef]

39. Jabońska, E.; Winkowska, M.; Winiewska, M.; Geurts, J.; Zak, D.; Kotowski, W. Impact of vegetation harvesting on nutrient removal and plant biomass quality in wetland buffer zones. Hydrobiologia 2021, 848, 3273-3289. [CrossRef]

40. Azhdarpoor, A.; Abbasi, L.; Samaei, M.R. Investigation of a new double-stage aerobic-anoxic continuous-flow cyclic baffled bioreactor efficiency for wastewater nutrient removal. J. Environ. Manag. 2018, 211, 1-8. [CrossRef] [PubMed]

41. McConnaughay, K.D.M.; Coleman, J.S. Biomass allocation in plants ontogeny or optimality a test along three resource gradients. Ecology 1999, 80, 2581-2593. [CrossRef]

42. Busch, J.; Mendelssohn, I.A.; Lorenzen, B.; Brix, H.; Miao, S. Growth responses of the Everglades wet prairie species Eleocharis cellulosa and Rhynchospora tracyi to water level and phosphate availability. Aquat. Bot. 2004, 78, 37-54. [CrossRef]

43. Rea, N.; Ganf, G. Water depth changes and biomass allocation in two contrasting macrophytes. Mar. Freshw. Res. 1994, 45, 1459-1468. [CrossRef]

44. Vojtíšková, L.; Munzarová, E.; Votrubová, O.; Řihová, A.; Juřicová, B. Growth and biomass allocation of sweet flag (Acorus calamus L.) under different nutrient conditions. Hydrobiologia 2004, 518, 9-22. [CrossRef]

45. Xie, Y.; An, S.; Wu, B. Resource allocation in the submerged plant Vallisneria natans related to sediment type, rather than water-column nutrients. Freshw. Biol. 2005, 50, 391-402. [CrossRef]

46. Walton, C.R.; Zak, D.; Audet, J.; Petersen, R.J.; Lange, J.; Oehmke, C.; Wichtmann, W.; Kreyling, J.; Grygoruk, M.; Jabłońska, E.; et al. Wetland buffer zones for nitrogen and phosphorus retention: Impacts of soil type, hydrology and vegetation. Sci. Total. Environ. 2020, 727, 138709. [CrossRef] [PubMed]

47. Schipper, L.A.; Robertson, W.D.; Gold, A.J.; Jaynes, D.B.; Cameron, S.C. Denitrifying bioreactors-An approach for reducing nitrate loads to receiving waters. Ecol. Eng. 2010, 36, 1532-1543. [CrossRef]

48. Teiter, S.; Mander, $\mathrm{U}$. Emission of $\mathrm{N}_{2} \mathrm{O}, \mathrm{N}_{2}, \mathrm{CH}_{4}$, and $\mathrm{CO}_{2}$ from constructed wetlands for wastewater treatment and from riparian buffer zones. Ecol. Eng. 2005, 25, 528-541. [CrossRef]

49. Huang, X.; Lei, S.; Wang, G.; Zeng, B. A wetland plant, Phalaris arundinacea, accumulates nitrogen and phosphorus during senescence. Environ. Sci. Pollut. Res. 2020, 27, 38928-38936. [CrossRef]

50. Armstrong, J.; Armstrong, W.; Beckett, P.M. Phragmites australis: Venturi- and humidity induced pressure flows enhance rhizome aeration and rhizosphere oxidation. New Phytol. 1992, 120, 197-207. [CrossRef] 